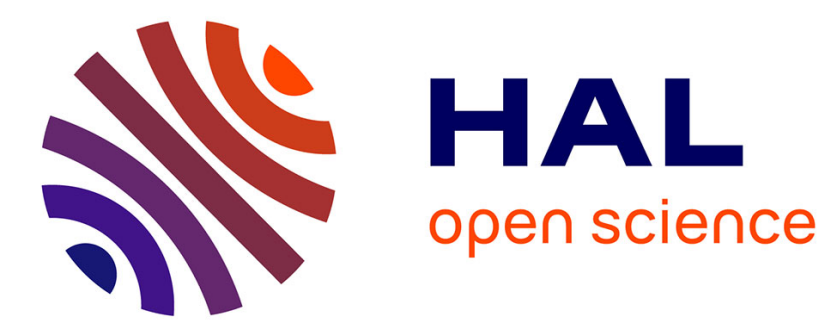

\title{
Use of pectino-cellulolytic enzymes for improving extraction of phloem-limited plant viruses as exemplified by the rice tungro virus complex
}

Swatantra K. Singh, Abburi Anjaneyulu, Hervé Lapierre

\section{To cite this version:}

Swatantra K. Singh, Abburi Anjaneyulu, Hervé Lapierre. Use of pectino-cellulolytic enzymes for improving extraction of phloem-limited plant viruses as exemplified by the rice tungro virus complex. Agronomie, 1984, 4 (5), pp.479-484. hal-00884662

\section{HAL Id: hal-00884662 https://hal.science/hal-00884662}

Submitted on 1 Jan 1984

HAL is a multi-disciplinary open access archive for the deposit and dissemination of scientific research documents, whether they are published or not. The documents may come from teaching and research institutions in France or abroad, or from public or private research centers.
L'archive ouverte pluridisciplinaire HAL, est destinée au dépôt et à la diffusion de documents scientifiques de niveau recherche, publiés ou non, émanant des établissements d'enseignement et de recherche français ou étrangers, des laboratoires publics ou privés. 


\title{
Use of pectino-cellulolytic enzymes for improving extrac- tion of phloem-limited plant viruses as exemplified by the rice tungro virus complex
}

\author{
Swatantra K. SINGH ( $\left.{ }^{1}\right)$, Abburi ANJANEYULU \& Hervé LAPIERRE (*) \\ Central Rice Research Institute, Cuttack - 753006 (Orissa) India \\ ${ }^{*}$ ) I.N.R.A., Station de Pathologie végétale, F-78000 Versailles
}

SUMMARY

Rice tungro virus complex (RTV-C), consisting of tungro spherical and tungro bacilliform viruses, is phloemlimited and transmitted principally by leafhoppers Nephotettix spp. in a semi-persistent manner ; it has been successfully purified using pectino-cellulolytic enzymes. The enzymes (driselase, pectolyase Y-23, macerozyme R-10 and cellulase "Onazuka" R-10) were used alone or in different combinations on the fibrous residue obtained from the first grinding and filtration of RTV-C infected shoots of rice cultivar "Taichung Native-1". The fibrous residue was homogenized once or successively in citrate buffer $\mathrm{pH} 6$ along with enzyme or a mixture of enzymes and incubated with shaking. The filtrate was adjusted to $\mathrm{pH} 7$ and the virus particles were purified by clarifying extracts with chloroform, precipitation of virus by differential centrifugation and sucrose density gradients. The quantity of the virus-complex obtained from different experimental conditions was compared by the measurement of the surface of the absorption at $260 \mathrm{~nm}$ in sucrose density gradients. In the presence of the three enzyme systems utilized, a major increase ( 1.39 to 3.12 times) in the virus yield was obtained from the treatment of fibrous residue. The action of the enzymes utilized in these systems appears to be additive, and this point is discussed. The enzyme method described here and earlier for some luteoviruses may be useful for extraction and purification of other phloem-limited viruses.

Additional key words : Rice, semi-persistent transmission, leafhoppers, luteovirus, extraction from fibrous residues, pectinase, cellulase, driselase, pectolyase $Y-23$.

Utilisation d'enzymes pectino-cellulolytiques pour améliorer l'extraction des virus à localisation phloémique : cas du "Rice tungro virus", complexe viral du riz.

Le complexe viral du riz dénommé « Rice tungro virus complex » (RTV-C) localisé aux cellules du phloème, transmis principalement par les cicadelles du genre Nephotettix sur le mode semi-persistant, a été purifié suivant un protocole mettant en jeu l'action d'enzymes pectino-cellulolytiques. Les enzymes et les complexes enzymatiques (driselase, pectolyase Y-23, macérozyme R-10 ou cellulase « Onazuka » R-10) ont été utilisés seuls ou successivement sur les résidus fibreux obtenus après broyage et filtration de pousses de riz de la variété « Taichung Native 1 ». Les résidus fibreux sont homogénéisés dans un tampon citrate pH 6 en présence des enzymes pectino-cellulolytiques puis incubés en milieu agité pendant $2 \mathrm{~h}$ à $28 \pm 1{ }^{\circ} \mathrm{C}$. La fraction soluble est amenée à $\mathrm{pH} 7$ et la purification des particules virales s'effectue de la facon suivante : après clarification de l'extrait par le chloroforme, deux ultra-centrifugations différentielles sont réalisées, la première est effectuée en présence d'un coussin de sucre. Pour les différentes conditions expérimentales, les quantités de virus obtenues sont comparées par la mesure de la surface des zones d'absorption à $260 \mathrm{~nm}$ des particules virales après leur migration dans un gradient de saccharose. Avec les différents systèmes enzymatiques utilisés pour les résidus fibreux, des accroissements notables $(1,39$ à 3,11$)$ des rendements d'extraction du complexe viral sont obtenus à partir de ces résidus. L'action des trois systèmes enzymatiques suggère des effets complémentaires qui sont discutés. Ce type d'extraction enzymatique réservé aux résidus fibreux, décrit ici sur le RTV-C et antérieurement pour certains lutéovirus, devrait être applicable aux autres groupes de virus à localisation phloémique.

Mots-clés additionnels : Riz, transmission semi-persistante, cicadelles, lutéovirus, extraction à partir de résidus fibreux, pectinase, cellulase, driselase, pectolyase $Y-23$. 


\section{INTRODUCTION}

Improving yields of viruses localized in specialized plant cells has been a concern of virologists for many years. This is particularly true for certain phloemlimited plant viruses which occur in low concentrations and are difficult to extract from plants (RocHOw \& BRAKKE, 1964 ; KOJIMA et al., 1969). Even when extraction has seemed possible, yield of such viruses has been very low (BRAKKE \& ROCHOW, 1974 ; KOJIMA \& TAMADA, 1976). This fact has necessitated development of a suitable extraction and purification procedure, considering particularly aspects of localization of virus within the plant in order to obtain maximum virus yield (TAKAMI \& KUBO, 1979 ; WATERHOUSE \& MURANT, 1981; HAMMOND et al., 1983). This is indeed the case for a large number of important plant viruses which have not been purified in quantities sufficient for various fundamental and applied studies, and await a proper place in the current system of virusclassification (MATTHEWS, 1982). The viruses causing "tungro", one of the most widespread and destructive diseases of rice (Oryza sativa L.) in the South and South-East Asian countries, represent one such example. The disease, firstly described by ANON. (1964), is now known to represent a group of similar diseases in the region (OU, 1972 ; SAITO, 1977 ; HIBINO et al., 1978). The disease had been thought to be caused by an isometric virus "rice tungro virus" (RTV) (GALVEZ, 1967, 1968, 1971 ; GALVEZ et al., 1971 ; OU, 1972 ; FAVALI et al., 1975), till SAITO et al. $(1975,1976)$ and SAITO (1977) observed two types of virus particles (spherical and bacilliform) in plants affected with tungro and similar diseases with the exception of "Waika" disease and mild strain of RTV in the Philippines. Recent observations from different countries confirm association of two types of particles with the disease and plants showing severe symptoms of tungro have always been found associated with the "rice tungro virus complex" (RTV-C) containing both types of particles (HIBINO et al., 1978, 1979 ; MISHRA et al., 1979 ; MILNE et al., 1981; OMURA et al., 1981; SINGH et al., 1984. Both components of RTV-C are phloem-limited (SAITO et al., 1976) and transmitted in semi-persistent manner by the principal leafhopper vector Nephoiettix virescens Distant (HIBINO et al., 1978,1979 ; S.NGH et al., unpublished).

In the present investigation we have attempted to facilitate the extraction of this phloem-limited virus complex from infected plant tissues using pectinocellulolytic enzymes and have tried to analyse the action of these enzymes.

\section{MATERIALS AND METHODS}

\section{A. Virus and plant materials}

RTV-C Cuttack II isolate was utilized for this study. Rice plants of cultivar "Taichung Native 1" (TN-1) were grown and maintained in the glasshouse at $23 \pm 5{ }^{\circ} \mathrm{C}$ with a photoperiod of 8-9 hours. 15-day old seedlings vere inoculated by viruliferous $N$. virescens ( 2 leafhoppers per seedling). The leafhoppers, collected from healthy colonies grown in the net-house, were given $24 \mathrm{~h}$ each of acquisition and inoculation feedings. The inoculated seedlings were sprayed with an insecticide (Dimecron) and observed for 20 days for selection of plants showing typical symptoms of tungro (yellow to yellow-orange discoloration of leaves and stunting of plants). These experimentally infected plants were uprooted, fumigated and brought to CNRA, Versailles, the site of this investigation, where they were kept at $4 \pm 1{ }^{\circ} \mathrm{C}$.

\section{B. Virus purification}

$30 \mathrm{~g}$ or shoots (i.e. entire above-ground portion) of the RTV-C infected plants in each of the three replications was cut into small pieces and macerated for $2 \mathrm{mn}$ in a Waring blender with $0.1 \mathrm{M}$ phosphate buffer $\mathrm{pH} 7.15$ containing $0.2 \% 2$-mercaptoethanol $(3 \mathrm{~V}$ of buffer/g plant tissue). The extract was filtered through two layers of muslin cloth and the filtrate and fibrous residue were processed independently. The entire operation was carried out in a cold chamber at $4 \pm 1{ }^{\circ} \mathrm{C}$. Extraction and clarification procedures were usually compared by dividing tissue batches equally among two or more concurrent treatments.

\section{Purification from shoots}

The filtrate coming from a known quantity of infected shoots was emulsified with $1 / 3(\mathrm{~V} / \mathrm{V})$ chloroform while stirring for $20 \mathrm{mn}$. It was then allowed to sediment for $10 \mathrm{mn}$ and subsequently the emulsion was broken by centrifugation at $8000 \mathrm{~g}$ for $10 \mathrm{mn}$ in a Sorval SS3 centrifuge. The supernatant fluid was again clarified at $10000 \mathrm{~g}$ for $13 \mathrm{mn}$. This supernatant was subjected to two cycles of differential centrifugation $(100000 \mathrm{~g}, 2 \mathrm{~h} 30 \mathrm{mn} ; 13000 \mathrm{~g}, 15 \mathrm{mn} ; 100500 \mathrm{~g}$, $2 \mathrm{~h}$ ) in a Beckman L8-70 ultracentrifuge. During the first ultracentrifugation, the clarified supernatant was layered over a $2.5 \mathrm{ml}$ sucrose cushion of $25 \%(\mathrm{~W} / \mathrm{V})$ sucrose in $0.05 \mathrm{M}$ phosphate buffer $\mathrm{pH} 7.15$. The final pellet after the second ultracentrifugation was suspended in $1-1.5 \mathrm{ml}(1 / 300 \mathrm{~V}$ of starting stock solution) $0.05 \mathrm{M}$ phosphate buffer $\mathrm{pH} 7.15$ and centrifuged for $1 \mathrm{~h} 30 \mathrm{mn}$ at $197000 \mathrm{~g}$ in a SW41 rotor at $4{ }^{\circ} \mathrm{C}$. The gradients were scanned in an ISCO density gradient fractionator Model 185 and U.A.5 Ultra violet (U.V.) analyser. The fraction containing the virus was collected and diluted with an approximately equal volume of $0.05 \mathrm{M}$ phosphate buffer $\mathrm{pH} 7$ and concentrated by centrifugation at $100500 \mathrm{~g}$ for $2 \mathrm{~h} 30 \mathrm{mn}$. The virus pellets were suspended in $0.05 \mathrm{M}$ phosphate buffer $\mathrm{pH} 7$ and the preparations were stored frozen or at $4{ }^{\circ} \mathrm{C}$ depending on the objectives of further use.

\section{Purification from fibrous residue}

Known quantities of fibrous residue from the first maceration of shoots were homogenized with $0.1 \mathrm{M}$ citrate buffer $\mathrm{pH} 6$ containing $1 \% 2$-mercaptoethanol $(4 \mathrm{~V} / \mathrm{g}$ fibre) with either $1 \%(\mathrm{~W} / \mathrm{V})$ driselase (Kyowa Hakko Kogygo Co. Ltd. Tokyo, Japan) or $0.2 \%$ pectolyase Y-23 (Seishin Pharmaceutical Co. Ltd. Tokyo, Japan) or a combination of $0.2 \%$ macerozyme R-10 plus $0.5 \%$ cellulase "Onazuka" R-10 (Kinki Yakult Mfg. Co. Ltd. Nishinomiya, Japan). The homogenate was incubated for $2 \mathrm{~h}$ at $28 \pm 1{ }^{\circ} \mathrm{C}$ with shaking (40 oscillations $/ \mathrm{mn}$ ) in a water aquatherm. The incu- 
bated homogenate was kept at $4{ }^{\circ} \mathrm{C}$ for $2 \mathrm{~h}$, subsequently mixed in a Waring blender with $10 \%(\mathrm{~V} / \mathrm{V})$ $0.1 \mathrm{M}$ phosphate buffer $\mathrm{pH} 8$ (to lower the $\mathrm{pH}$ of the homogenate to 7) and filtered through two layers of muslin cloth. The supernatant was emulsified, clarified and subjected to two cycles of differential centrifugation followed by sucrose density-gradient centrifugation and finally scanned with ISCO density-gradient fractionator. The fibrous residues coming from the treatment of different enzymes were treated with the same quantity $(\mathrm{W} / \mathrm{V})$ of the respective enzymes and further processed in the same way to give again a supernatant and a fibrous residue. These fractions were processed for the third successive extraction and purification as above, except that the fibrous residue coming from the treatment of driselase was homogenized with $0.25 \%$ (W/V) macerozyme R-10 plus $0.4 \%$ cellulase "Onazuka" R-10 and $0.2 \%$ pectolyase Y-23, fibrous residue from pectolyase $\mathrm{Y}-23$ treatment was homogenized with $1 \%$ driselase plus $0.25 \%$ macerozyme R-10 and $0.4 \%$ cellulase and fibrous residue from the treatment of a mixture of macerozyme R-10 and cellulase "Onazuka" R-10 was homogenized with $1 \%$ driselase and $0.2 \%$ pectolyase $Y-23$. The supernatant was clarified and analysed as described. To compare the results and to determine the effectiveness of the enzyme treatments, a fraction of the fibrous residue was processed in the same manner, except that no enzyme was added to it at any stage of the purification to serve as a control.

\section{E. Virus yield estimation}

This essentially consists of the method as described by GALVEZ (1968) with some modifications. Sucrose density-gradient columns containing a fixed volume $(0.5 \mathrm{ml})$ of partially purified RTV-C coming from different preparations were analysed through a U.V. monitor. The amount of virus complex was quantified from weight of the support paper covering the absorption peak after its four fold enlargement.

\section{F. Electron-microscopy}

Negatively stained preparations in $1 \%$ neutral phosphotungstic acid (PTA), were examined under a Philips Electron microscope EM-300 at $80 \mathrm{kV}$.

\section{RESULTS}

\section{A. Extraction of the virus-complex}

\section{Clarifying chemicals}

Chemical clarification of the infected plant sap with chloroform $(1 / 3 \mathrm{~V} / \mathrm{V})$ or butanol $(8 \%)$, compared with no chemical clarification of the infected plant sap (control), indicated that the control gave more virus than treatment with either of the chemicals. However, virions purified without chemical clarification were contaminated with green chlorophyll pigments. Treatment with butanol resulted in loss of viral particles whereas chloroform emulsification eliminated most of the green pigments and gave better yield of RTV-C compared with the butanol treatment. Consequently chloroform emulsification was used in all further analyses.

\section{Extraction of RTV-C from whole shoots and shoot fibres by grinding}

Utilizing the method of extraction described in this paper, particularly macerating the infected shoots in a Waring blender, an equivalent amount of virus was obtained in the fibrous residue and in the sap obtained from this maceration (table 1). Virions from the residual fibres were extracted by regrinding these fibres in a Waring blender with or without enzymes (table 2).

\section{Enzyme-assisted extraction of $R T V-C$ from infec- ted shoot fibres}

Incubation of fibrous residue with an enzyme (driselase or pectolyase $\mathrm{Y}-23$ ) or a mixture of enzymes (macerozyme R-10 + cellulase "Onazuka" R-10) resulted in enhanced yield of the virus complex compared to the control (fig. 1). Virus yield increase depended on different enzymatic treatments (fig. 2).

\section{Second extraction from shoot fibres}

The quantity of virus-complex obtained in the presence of the second successive enzyme treatment was much lower (fig. 2) than that obtained in the first phase of the treatment. However, fibrous residue from tissues homogenized with different enzymes yielded enough virus to be detected on sucrose density gradient profiles whereas re-extraction from fibrous residue without enzyme treatment yielded no detectable virus.

\section{Third extraction from shoot fibres}

With the different systems of enzymes used, third successive extraction, as described in chap. II, resulted in a yield increase of the virus-complex com-

\section{TABLE 1}

Virus productivity index of $R T V$-C from infected rice shoots (variety $T N-1$ ) : comparison of virus content in sap and fibres. Rendement en RTV-C par unité de poids de pousses de riz infectées (cv. $T N-1)$. Comparaison des quantités de virus contenues dans le premier extrait de jus de plante et les résidus fibreux.

\begin{tabular}{|c|c|c|c|c|}
\hline \multicolumn{5}{|c|}{ Virus productivity Index $\left({ }^{1}\right)$} \\
\hline \multirow{3}{*}{ Soluble phase $\left({ }^{2}\right)$} & \multicolumn{4}{|c|}{ Fibres $\left({ }^{3}\right)$} \\
\hline & \multirow{2}{*}{ Without enzymes } & \multicolumn{3}{|c|}{ With enzymes $\left({ }^{4}\right)$} \\
\hline & & I & II & III \\
\hline 5.2 & 5.4 & 16.8 & 11.2 & 7.5 \\
\hline
\end{tabular}

(1) Relative virus productivity per unit of tissue, value calculated from profiles of sucrose density gradient analysis of extracted virus (average of three replications).

(2) Soluble phase or sap from first grinding of infected shoots.

$\left({ }^{3}\right)$ Residual fibres from above crushing.

( $)$ Treatment with enzymes :

I - Driselase $(1 \% \mathrm{~W} / \mathrm{V})$

II - Pectolyase Y-23 $(0.2 \% \mathrm{~W} / \mathrm{V})$

III - Macerozyme R-10 (0.2\% W/V) + Cellulase «Onozuka » R-10 $(0.5 \% \mathrm{~W} / \mathrm{V})$. 
TABLE 2

Yields of RTV-C from infected residual fibres : effect of different enzyme treatments on three successive extractions.

Rendement en $R T V-C$ à partir des résidus fibreux. effet des différents traitements enzymatiques lors des trois extractions successives.

\begin{tabular}{|c|c|c|c|}
\hline $\begin{array}{l}\text { Type of } \\
\text { Protocol }\end{array}$ & $\begin{array}{c}\text { No. of } \\
\text { successive } \\
\text { extraction }\end{array}$ & Treatments & $\begin{array}{l}\% \text { of total Total yield } \\
\text { yield in values of } 3 \\
\text { each consecutive } \\
\left.\text { extraction extractions( }{ }^{*}\right)\end{array}$ \\
\hline
\end{tabular}

\begin{tabular}{|c|c|c|c|c|}
\hline \multirow[t]{3}{*}{1} & I & $\begin{array}{l}\text { Extraction without } \\
\text { enzyme treatment } \\
\text { (control) }\end{array}$ & 100 & \multirow[t]{3}{*}{5.4} \\
\hline & II & $\begin{array}{l}\text { Extraction without } \\
\text { enzyme treatment } \\
\text { (control) }\end{array}$ & 0 & \\
\hline & III & $\begin{array}{l}\text { Extraction without } \\
\text { enzyme treatment } \\
\text { (control) }\end{array}$ & 0 & \\
\hline \multirow{4}{*}{$2 \mathrm{~A}$} & & $\begin{array}{l}\text { Extraction with } \\
\text { enzyme treatments }\end{array}$ & 85 & \multirow{4}{*}{19.76} \\
\hline & 1 & Driselase $1 \%$ & 85 & \\
\hline & II & $\begin{array}{l}\text { Extraction with } \\
\text { enzyme treatments } \\
\text { Driselase } 1 \%\end{array}$ & 5.36 & \\
\hline & III & $\begin{array}{c}\text { Macerozyme R-10 } \\
0.25 \%+ \\
\text { Cellulase "Onazuka" } \\
\text { R-10 } 0.4 \%++ \\
\text { Pectolyase Y-23 } 0.2 \%\end{array}$ & 9.61 & \\
\hline \multirow[t]{3}{*}{$2 \mathrm{~B}$} & I & Pectolyase Y-23 $0.2 \%$ & 82.78 & \multirow{3}{*}{13.53} \\
\hline & II & Pectolyase Y-23 $0.2 \%$ & 8.35 & \\
\hline & III & $\begin{array}{c}\text { Driselase } 1 \%+ \\
\text { Macerozyme R-10 } \\
0.25 \%+ \\
\text { Cellulase "Onazuka" } \\
\text { R-10 } 0.4 \%\end{array}$ & 8.87 & \\
\hline \multirow[t]{3}{*}{$2 \mathrm{C}$} & I & $\begin{array}{c}\text { Macerozyme R-10 } \\
0.2 \%+ \\
\text { Cellulase "Onazuka" } \\
\text { R-10 } 0.5 \%\end{array}$ & 78.37 & \multirow{3}{*}{9.57} \\
\hline & II & $\begin{array}{c}\text { Macerozyme R-10 } \\
0.2 \%+ \\
\text { Cellulase "Onazuka" } \\
\text { R-10 } 0.5 \%\end{array}$ & 9.10 & \\
\hline & III & $\begin{array}{c}\text { Driselase } 1 \% \\
+ \\
\text { Pectolyase Y-23 }\end{array}$ & 12.53 & \\
\hline
\end{tabular}

$\left({ }^{*}\right)$ Virus yield value calculated from virus productivity per unit of residual fibres obtained in three consecutive extractions (average of three replications).

pared to that obtained in the second successive extraction with the repeated use of the same enzyme or enzyme mixture in their previous concentrations (fig. 2).

\section{Virus yield estimation}

As it was not possible to separate clearly the two types of virus particles associated with this complex, their exact yield per unit of plant material could not

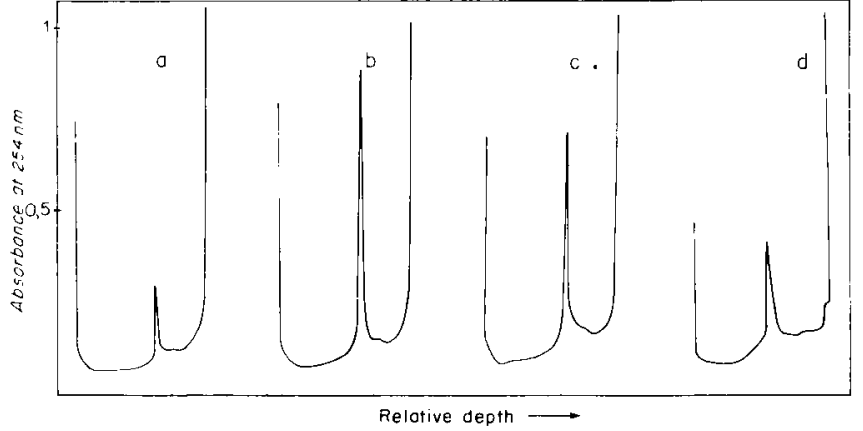

Figure 1

U.V. absorptiometer traces of linear sucrose density gradients of the purified viral preparations from the first enzyme treatment of $15 \mathrm{~g} \mathrm{RTV-C}$ infected residual plant fibres.

(a) control (no enzyme treatment)

(b) $1 \%$ driselase ; (c) $0.2 \%$ pectolyase $Y-23$;

(d) $0.2 \%$ macerozyme $R-10+0.5 \%$ cellulase "Onazuka" $R-10$. Gradients prepared in 10 to $40 \%$ sucrose solution in $0.05 \mathrm{M}$ phosphate buffer $p H 7$ and scanned with $1 \mathrm{~cm}$ light path cell and a sensitivity range of I Optical Density unit at $254 \mathrm{~nm}$ wavelength.

Courbes d'absorption en U.V. du contenu de tubes de gradients de saccharose de préparations virales obtenues après un premier traitement enzymatique de $15 \mathrm{~g}$ de résidus fibreux de pousses de riz infectées par le RTV-C.

(a) Témoin (pas de traitement enzymatique);

(b) I p. 100 driselase ; (c) 0,2 p. 100 pectolyase $Y$-23 ;

(d) 0,2 p. 100 macerozyme $R-10+0,5 p .100$ cellulase «Onazuka » $R-10$.

Les gradients de saccharose (10-40 p. 100) sont préparés dans un tampon phosphate $0,05 \mathrm{MpH} 7$. Leur analyse s'effectue à une longueur d'onde de $254 \mathrm{~nm}$ à travers une cellule de $1 \mathrm{~cm}$ de trajet optique et une sensibilité de l'unité de densité optique.

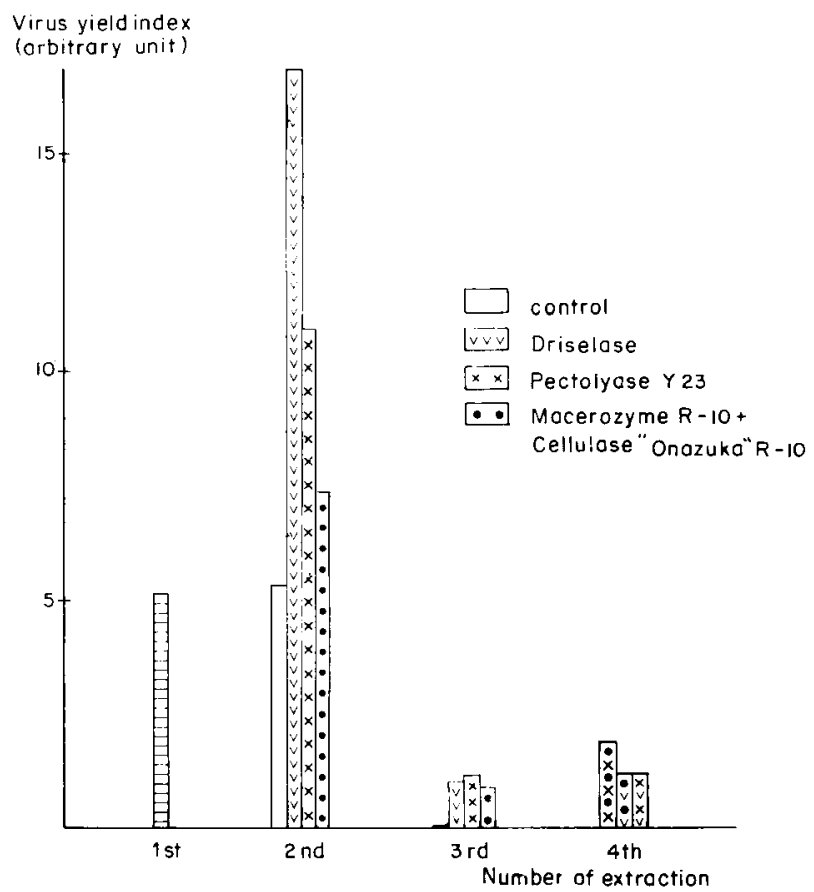

Figure 2

$R T V-C$ yield index obtained from infected shoots at 4 successive grindings with or without enzyme (see text for details). The first grinding was done without enzyme treatment.

Rendements d'extraction du RTV-C pour les 4 broyages successifs en présence ou en absence d'enzyme (voir texte). Le premier broyage est effectué sans traitement enzymatique. 
be calculated. However, an estimation could be made by measurement of optical density (O.D.) units of the purified virus at $260 \mathrm{~nm}$. For the three purifications the value of 6 to 10 O.D. units per $\mathrm{kg}$ of shoots was obtained. Virus yield increase may be represented in one of the following two ways : either the different systems of enzymes or enzyme mixtures utilized in their respective concentration have brought about an increase of 1.39 to 3.12 times more virus yield only from the residual fibres or 3 to 5 times more yield of RTV-C has been obtained by utilizing both supernatant and the residual fibres of the RTV-C infected shoots.

\section{B. Characteristics of the virus-complex}

\section{Absorbance}

The ultra-violet absorbance spectra of the isolated RTV-C was typical of a nucleo-protein, with a maximum at $260 \mathrm{~nm}$ and a minimum at $240 \mathrm{~nm}$. The A260/A280 ratio of the purified preparation was 1.58. Two possible explanations for the higher value of this ratio of RTV-C compared to that proposed for RTV by GALVEZ $(1968,1971)$ are that either our method of purification eliminated more contaminants or the percentage of two types of particles associated with our diseased plants was different from those utilized by GALVEZ (1968). As the present study deals with a virus-complex, we have not estimated from this absorbance ratio the percentage of nucleic acid present in the particles.

\section{Electron microscopy}

Observations of purified RTV-C in negative coloration indicate the presence of isometric (about $28 \mathrm{~nm}$ in diameter) and bacilliform (about $33 \mathrm{~nm}$ in diameter and $175 \mathrm{~nm}$ in length) particles.

The isometric particles were in greater number than the bacilliform particles when observations were made by mixing fraction containing virus with PTA at $\mathrm{pH} 5$ or 7 .

\section{Polydispersion of RTV-C particles}

In sucrose density gradient analysis we noticed variation in the profile of U.V. absorption of the fraction containing purified RTV-C. To be precise, molecules sedimenting faster than the main component were observed in variable quantities. Electron microscopic observation of the fraction containing molecules of higher sedimentation coefficients revealed the presence of more bacilliform particles.

\section{DISCUSSION AND CONCLUSIONS}

In the present study utilization of pectino-cellulolytic enzymes has greatly facilitated the extraction of phloem-limited RTV-C. In all the previous methods of RTV or RTV-C purification (GALVEZ, 1968 ; SAITO, 1977 ; MISHRA et al., 1981 ; MILNE et al., 1981), the fibrous residues of infected plant tissues were not utilized. Thus this fraction has been going to waste, resulting in a lower virus yield. We have utilized these fibrous residues for RTV-C extraction and have found that compared with sap, these residues contain about an equal amount of virions, the yield of which can be increased more than threefold by the use of different enzymes (table 2). Our results indicate that incubation of fibrous residue with driselase is more efficient in extracting RTV-C than other enzyme combinations tested at their respective concentrations. The superiority of driselase over the other enzymes used in the extraction and purification procedure can be partially explained by the fact that it is a compound enzyme system having strong cellulase and pectinase activities. Besides these activities, it has some laminarinase, xylanase and amylase activity which possibly help in the extraction process. Although pectolyase Y-23 contains mainly pectinase, in our experiments it gave a better result compared with the treatment with a mixture of macerozyme R-10 $(0.2 \%)$ plus cellulase «Onazuka » R-10 $(0.5 \%)$. The high activity of endo-pectinlyase (endo-PL) and endo-polygalacturonase (endo-PG) and the presence of a factor which stimulates tissue maceration by endo-PL and endo-PG activities of pectolyase Y-23 (NAGATA \& ISHII, 1979) could partially explain its better activity compared to that of the mixture of cellulase plus macerozyme. Similar results with barley yellow dwarf virus (BYDV) have also been obtained using pectolyase Y-23 (LAPIERRE, unpublished, 1983). The relative efficiency of macerozyme and cellulase in different concentrations and proportions was not determined.

The results of the second successive extraction from fibrous residues indicated that repeated use of the same enzyme treatment was not very effective in extracting a greater quantity of virions. The virions could not be extracted from the material incubated without enzyme. This suggests that only extended blending and endogenous enzyme effects observed for BYDV by HAMMOND et al. (1983) are insufficient for extraction of RTV-C after the first extraction from the fibrous residue. In the different systems of enzymes tested, the final dose of these enzymes during the third successive extraction brought about an increase in the virus yield value compared to that obtained in the second successive extraction. A higher increase in virus yield value at this stage suggests a complementary effect of these enzymes which was obvious in all the three enzyme combinations tested. The difference in total yield of the virus complex obtained after utilizing three enzyme systems in different order during the extraction was not very clear. Possibly with the increasing time of incubation at $28 \pm 1^{\circ} \mathrm{C}$, there is a progressive degradation of virus particles but we did not test this hypothesis. Utilization of pectino-cellulolytic enzymes in the second and third successive extractions was not so efficient as in the first extraction. Their subsequent use after a first extraction would only be needed for special purposes. It appears that a mixture of enzymes with complementary effects would give better results than the use of the same enzyme or enzyme mixture after the first extraction from the fibrous residue. The different enzymes utilized by us and some other workers for improving yields of phloem-limited viruses mainly have pectinase and cellulase activities. Some of these enzymes have been found to eliminate much host material in the early sta- 
ges of virus extraction without adversely affecting the virions, thus facilitating the production of highly purified virus preparations. Pectinolytic enzymes have also been utilized as clarifying agents in the extraction of certain plant viruses with good results (ADOMAKO \& ODURO, 1974 ; LOT pers. comm., 1983). In the extraction of phloem-limited viruses, these enzymes eliminate the need for extended grinding or regrinding of the fibrous residues and reduce the chance of excessive heating and degradation of virus particles during their extraction. Two principal and non-exclusive hypotheses may explain the action of enzymes in the extraction of phloem-limited viruses : while facilitating the maceration activity of the plant tissues, enzymes either liberate the virions confined in the phloem cells or they liberate the virions retained directly or indirectly by pectic or cellulosic substances of the tissues. According to the first hypothesis enzymes with both pectinase and cellulase activities are necessary to liberate the virions from the specialized cells. According to the second hypothesis enzymes with only one main type of enzymatic activity (either pectinase or cellulase) are needed to liberate virions from specific sites. However, in our experiments with RTV-C and those of LAPIERRE (unpublished, 1983) with BYDV, significant increase in yield of these two phloem-limited viruses was obtained by using pectolyase Y-23 alone. Treatment with either a compound enzyme like drise- lase (TAKAMI \& KUBO, 1979; WATERHOUSE \& MURANT, 1981 and our present results) or a mixture of enzymes providing optimum pectinase and cellulase activities in sufficient amount gave better results (HAMMOND et al., 1983 ; SINGH et al., unpublished data) than treatment with enzymes having either pectinase or cellulase activity alone. These results do not allow us to exclude one or other of the hypotheses proposed. In particular the good efficacy of the pectolyase could be explained either by its activity in liberating virions from the pectic substances or by its partially destabilizing activity on the cell wall structure of phloem tissues. The exact mode of action of enzymes in the extraction and purification of phloemlimited viruses needs further investigation. This method of extraction, described for RTV-C, may be useful in increasing yields of many other phloem or partially phloem-limited plant viruses belonging to different families.

Received August 16, 1983. Accepted January 26, 1984.

\section{ACKNOWLEDGEMENTS}

The first author is thankful to Dr. H. K. PANDE, Director C. R. R. I. Cuttack (Orissa) for encouragement and facilities and to the French Ministry of External Relations, for financial support.

\section{REFERENCES}

Adomako G. K., Oduro N. W., 1974. Purification of cocoa necrosis virus from cocoa leaves. Phytopathology, 64, 1325-1330.

Anon, 1964. Repori Int. Rice Res. Inst., 1963, 114

Brakke M. K., Rochow W. F., 1974. Ribonucleic acid of barley yellow dwarf virus. Virology, 61, 240-248.

Favali M. A., Pellegrini S., Bassi M., 1975. Ultrastructural alterations induced by rice tungro virus in rice leaves. Virology, 66, 502507.

Galvez G. E., 1967. The purification of virus-like particles from rice tungro virus-infected plants. Virology, 33, 357-359.

Galvez G. E., 1968. Purification and characterization of rice tungro virus by analytical density- gradient centrifugation. Virology, $35,418-426$

Galvez G. E., 1971. Rice tungro virus. In "Descriptions of plant viruses", No. 67, CMI, Assoc. Appl. Biol., Kew, Surrey, England.

Gaivez G. E., Shikata E., Miah M. S. A., 1971. Transmission and electron-microscopy of a rice tungro virus strain. Phytopathol. Z., 70, 53-61.

Hammond J., Lister R. M., Foster J. E., 1983. Purification, identity and some properties of an isolate of barley yellow dwarf virus from Indiana. J. Gen. Virol., 64, 667-676.

Hibino H., Roechan M., Sudarisman S., 1978. Association of two types of virus particles with penyakit habang (tungro disease) of rice in Indonesia. Phytopathology, 68, 1412-1416.

Hibino H., Saleh N., Roechan M., 1979. Transmission of two kinds of rice tungro-associated viruses by insect vectors. Phytopathology, 69, 1266-1268.

Kojima M., Shikata E., Sugawara M., Murayama D., 1969. Purification and electron microscopy of potato leafroll virus. Virology, 39, $162-174$.

Kojima M., Tamada T., 1976. Purification and serology of soyabean dwarf virus. Phytopathol. Z., 85, 237-250.

Matthews R. E. F., 1982. Classification and nomenclature of Viruses. Intervirology, 17, 1-199.
Milne R. G., Boccardo G., Ling K. C., 1981. Electron microscopy of particles of rice tungro virus complex. Int. Rice Res. Newsl., 6 (5), 13.

Mishra M. D., Niazi F. R., Basu A. N., Namprakash, 1981. Purification and electron microscopy of the spherical component in some Indian strains of rice tungro virus. Indian Phytopathol., 34 (4), 461-464.

Mishra M. D., Saito Y., Basu A. N., Niazi F. R., 1979. Etiology of two strains of rice tungro virus in India. Indian Phytopathol., 32 (2), 260-263.

Nagata T., Ishii S., 1979. A rapid method for isolation of mesophyll protoplasts. Can. J. Bot., 57, 1820-1823.

Omura T., Inoue H., Thapa U. B., Saito Y., 1981. Association of rice tungro spherical virus and rice tungro bacilliform virus with the disease in Janakpur, Nepal. Int. Rice Res. Newsl., 6 (6), 14.

Ou S. H., 1972. Rice Diseases. Commonw. Mycol. Inst., Kew, Surrey. England, $368 \mathrm{p}$.

Rochow W. F., Brakke M. K., 1964. Purification of barley yellow dwarf virus. Virology, 24, 310-322.

Saito Y., Roechan M., Tantera D. M., Iwaki M., 1975. Small bacilliform particles associated with penyakit habang (tungro-like) disease of rice in Indonesia. Phytopathology, 65, 793-796.

Saito Y., I. Kaki M., Usugi T., 1976. Two kinds of particles found in the phloem cells of rice tungro and similar diseases (Abstr.), Ann. Phytopathol. Soc. Jpn., 42, 375 (In Japanese).

Saito Y., 1977. Inter-relationship among waika disease, tungro and other similar diseases of rice in Asia. Symp. on Virus diseases of tropical crops. Trop. Agric. Res. Ser. TARC., 10, 129-135.

Singh S. K., Bhaktavatsalam G., Lapierre H., Anjaneyulu A., 1983. Association of two types of virus particles in an isolate of rice tungro disease. Int. Rice Res. Newsl., 9 (2), 15.

Takami Y., Kubo S., 1979. Enzyme-assisted purification of two phloem-limited plant viruses : tobacco necrotic dwarf and potato leafroll. J. Gen. Virol., 44, 153-159.

Waterhouse P. M., Murant A. F., 1981. Purification of carrot red leaf virus and evidence from four serological tests for its relationship to luteoviruses. Ann. Appl. Biol., 97, 191-204. 